\title{
Purification and Characterization of HCV RNA-dependent RNA Polymerase from Korean Genotype 1b Isolate: Implications for Discovery of HCV Polymerase Inhibitors
}

\author{
Jeongmin Kim," Mikyoung Lee, and Yong-Zu Kim \\ Drug Discovery, LG Life Sciences, Ltd., R\&D Park, 104-1, Munji-dong, Yusung-ku, Daejeon 305-380, Korea \\ *E-mail: jmkimb@lgls.co.kr \\ Received December 23, 2004
}

\begin{abstract}
The nonstructural protein 5B (NS5B) of hepatitis $\mathrm{C}$ virus (HCV) is the viral RNA-dependent RNA polymerase (RdRp), which is the essential catalytic enzyme for the viral replication and is an appealing target for the development of new therapeutic agents against $\mathrm{HCV}$ infection. A small amount of serum from a single patient with hepatitis C was used to get the genome of a Korean HCV isolate. Sequence analysis of NS5B 1701 nucleotides showed the genotype of a Korean isolate to be subtype 1b. The soluble recombinant HCV NS5B polymerase lacking the C-terminal 24 amino acids was expressed and purified to homogeneity. With the highly purified NS5B protein, we established in vitro systems for RdRp activity to identify potential polymerase inhibitors. The rhodanine family compounds were found to be potent and specific inhibitors of NS5B from high throughput screening (HTS) assay utilizing the scintillation proximity assay (SPA) system. The binding mode of an inhibitor was analyzed by measuring various kinetic parameters. Lineweaver-Burk plots of the inhibitor suggested it binds not to the active site of NS5B polymerase, but to an allosteric site of the enzyme. The activity of NS5B in in vitro polymerase reactions with homopolymeric RNA requires interaction with multiple substrates that include a template/primer and ribonucleotide triphosphate. Steady-state kinetic parameter, such as $K m$, was determined for the ribonucleotide triphosphate. One of compounds found interacts directly with the viral polymerase and inhibits RNA synthesis in a manner noncompetitively with respect to UTP. Furthermore, we also investigated the ability of the compound to inhibit NS5B-directed viral RNA replication using the Huh7 cell-based HCV replicon system. The investigation is potentially very useful for the utility of such compounds as anti-hepatitic agents.
\end{abstract}

Key Words : HCV, Polymerase, Inhibitor

\section{Introduction}

$\mathrm{HCV}$ infection is the leading cause of sporadic, posttransfusion, non-A non-B hepatitis. ${ }^{1,2}$ One hundred seventy million people worldwide are thought to be infected with hepatitis $\mathrm{C}$ virus of which an estimated 4 million reside in the United States. ${ }^{3,4}$ Approximately $80 \%$ of infected individuals progress to chronic infection. Long term chronic $\mathrm{HCV}$ infection can lead to liver cirrhosis and to hepatocellular carcinoma. Currently, the recommended therapy is treatment with a combination of interferon alpha2b and ribavirin, which results in a sustained viral response (SVR) in $40 \%$ of patients. Investigational therapies using a combination of pegylated interferon and ribavirin have lead to a SVR in $54 \%$ of patients, but the response rate (42\%) of patients harboring HCV genotype 1 is lower. ${ }^{5-7}$ Consequently, additional therapies for $\mathrm{HCV}$ infection are needed. HCV is a positive-strand RNA virus belonging to the family Flaviviridae. ${ }^{8}$ This virus family also contains about 40 flaviviruses that are associated with human diseases, including the dengue fever viruses, yellow fever viruses and Japanese encephalititis virus. Like other RNA viruses, a virally encoded replication enzyme, RNA-dependent RNA polymerase (RdRp), plays a central role in viral RNA replication of $\mathrm{HCV}$ and other members of the family Flaviviridae. In the case of $\mathrm{HCV}$, the replication protein is termed "NS5B" (nonstructural protein 5B). ${ }^{2,9}$ RdRp proteins are the key components of the viral replicase complexes and therefore serve as attractive targets for antiviral development. $^{1,15}$

We cloned, expressed and purified the soluble recombinant HCV NS5B lacking the C-terminal 24 amino acids from a Korean isolate. We chose to determine the nucleotide sequence of a $\mathrm{HCV}$ isolate from a single individual diagnosed with acute hepatitis C. The entire NS5B nucleotide and deduced amino acid sequences of this $\mathrm{HCV}$ isolate were compared with the the reported full length genotype $1 \mathrm{~b}$ isolate. With the highly purified NS5B protein, we established in vitro systems for RdRp activity to identify potential polymerase inhibitors. To improve the chances of developing an effective $\mathrm{HCV}$ chemotherapeutic by targeting the HCV RNA-dependent RNA polymerase, it is necessary to gain a better understanding of the catalytic activity of the enzyme. Toward that end, this work has been conducted to investigate the enzymatic activity of the soluble, C-terminally truncated form of HCV NS5B, termed NS5Bt. We also measured inhibitory effects with a 50\% inhibitory concentration $\left(\mathrm{IC}_{50}\right)$ of several known inhibitors, and compared 
them to the reported values. In this report we describe the expression of the NS5B gene in E. coli, purification of the protein and characterization of the enzymatic activity. In addition kinetic data of an inhibitor indicated that the compound acts as an allosteric inhibitor that block the activity of the polymerase prior to the elongation step.

\section{Materials and Methods}

Serum Samples and Preparation of cDNA Clones. Serum samples were collected from a patient diagnosed with acute hepatitis C. HCV RNA was extracted from $100 \mu \mathrm{L}$ of serum with QIAamp Viral RNA Kit (Qiagen Inc.) in conditions recommended by the manufacturer. The isolated RNA was dissolved in DEPC-treated distilled water and stored in freezer until use. HCV single-stranded cDNA was synthesized from the above RNA with 3' polyA primer and 100 units of reverse transcriptase (SuperscriptII, BRL Life Technologies Inc.). Double-stranded cDNA was prepared from single-stranded cDNA with primer, NS5BF (GGGGCTAGCTCAATGTCCTACTCATGGACAGGC) by using Advantage cDNA PCR Kit (Clontech Inc.) in conditions recommended by the manufacturers.

Cloning, Expression, and Purification of Recombinant HCV NS5B from $\boldsymbol{E}$. coli. Standard recombinant DNA techniques were used to generate all the constructs. ${ }^{10}$ To construct pET21b-NS5Bt, a PCR product containing the cDNA region encoding amino acid 2420-2987 of the HCV polyprotein (the C-terminal 24 amino acids deleted NS5B protein) was cloned between the NheI and XhoI sites of pET21b (Novagen). The sequences of the primers, NS5BFNheI and NS5BtC-XhoI, are as follows:

NS5BF-NheI (GGGGCTAGCTCAATGTCCTA CTCATGGACAGGC)

NS5BtC-XhoI (CCCCCTCGAGCGGGCACGAGACAGGCTGTGA)

pT7-IRES-3' $X$ is a derivative of pcDNA3 (Invitrogen). Template cDNA was synthesized similarly from the isolated HCV RNA with 3'X58R (5'-GGGTCTAGATCATGCGGCTCACGGACCTTTCACAGCTAG-3') primer. PCR amplifications were performed from the above cDNA template using primer pairs of 5'-GGGTCTAGATCATGCGGCTCACGGACCTTTCACAGCTAG-3'/5'-TTGAGCCACTTGACCTACCTCAGATCATTG-3', and consecutively from first PCR product using 5'-CTCTCCAGGTGAGATCAATAGGGTGGCTTC-3'/5'-GGGTCTAGACATGATCTGCAGAGAGGCCAGTATCAGCACTCTCTGCAGTCATGCG GCTCA CGGACCTTTCACAGCTA-3' primers. Second PCR product was digested with HindIII and XbaI, cloned into the corresponding site in pcDNA3 plasmid, and named pT7-IRES-3' $X$.

C-terminal 24 amino acids deleted NS5B protein (NS5Bt) was expressed in E. coli BL21(DE3) (Novagen) by the following procedures. E. coli BL21(DE3) transformed with pET21b-NS5Bt was grown in Luria-Bertini medium containing $100 \mu \mathrm{g}$ of ampicillin per $\mathrm{ml}$ to an optical density at $600 \mathrm{~nm}(\mathrm{OD} 600)$ of 0.6 at $37^{\circ} \mathrm{C}$, and protein expression was induced at $15{ }^{\circ} \mathrm{C}$ for overnight by addition of $0.5 \mathrm{mM}$ isopropyl- $\beta$-D-thiogalactopyranoside (IPTG). Cell pellets were washed once with phosphate-buffered saline (PBS) and resuspended in lysis buffer $(20 \mathrm{mM}$ Tris [pH 7.5], $10 \%$ glycerol, $0.3 \mathrm{M} \mathrm{NaCl}, 10 \mathrm{mM}$ imidazole, $0.05 \%$ Nonidet $\mathrm{P}$ $40,2 \mathrm{mM} \beta$-mercaptoethanol and $1 \mathrm{mM}$ phenylmethylsulfonyl fluoride). After the suspension was sonicated on ice, the cleared lysate obtained by centrifugation at 15,000 rpm for 40 min was applied to a Hitrap Ni chelating resin (Amersham Biosciences). The bound proteins were washed thoroughly and eluted with the lysis buffer containing imidazole in a gradient manner from 20 to $300 \mathrm{mM}$. The NS5Bt proteins eluted with 100 to $150 \mathrm{mM}$ imidazole, were pooled and diluted with buffer A containing $20 \mathrm{mM}$ Tris [pH 7.5], 10\% glycerol, $1 \mathrm{mM}$ EDTA, $1 \mathrm{mM}$ dithiothreitol (DTT) to adjust the $\mathrm{NaCl}$ concentration to $150 \mathrm{mM}$. Proteins applied to a HiTrap Heparin resin (Amersham Biosciences), were eluted with a linear gradient from $200 \mathrm{mM}$ to $1 \mathrm{M}$ $\mathrm{NaCl}$. The fractions containing $\mathrm{NS5Bt}$ were pooled as a single peak between $450 \mathrm{mM}$ and $650 \mathrm{mM} \mathrm{NaCl}$, and dialyzed against $\mathrm{RdRp}$ buffer containing $20 \mathrm{mM}$ Tris [pH 7.0], $10 \%$ glycerol, $0.1 \mathrm{M} \mathrm{NaCl}, 5 \mathrm{mM} \mathrm{MgCl}, 10 \mathrm{mM} \mathrm{KCl}$, $1 \mathrm{mM}$ EDTA, and $1 \mathrm{mM}$ DTT. Finally the fractions were purified with a HiLoad Superdex 75 (Amersham Biosciences) column chromatography. The gel filtration profile indicates non-homogeneous folding, but all fractions have the enzymatic activities.

In vitro RdRp Assay. Gel-based RdRp assays were done essentially as described previously ${ }^{2}$ with some modifications. Gel-based RdRp assays were conducted by using a 404 base RNA representing the 3'-end of the positive strand from the HCV RNA (3'-X RNA) as a template. In brief, purified protein was incubated with $0.5 \mu \mathrm{g}$ of 3 '-X RNA in a total volume of $40 \mu \mathrm{L}$ of RdRp buffer (20 mM Tris, pH 7.0, 5 $\mathrm{mM} \mathrm{MgCl} 2,10 \mathrm{mM} \mathrm{KCl}, 10 \mathrm{mM} \mathrm{NaCl}, 1 \mathrm{mM}$ EDTA, $1 \mathrm{mM}$ DTT) supplemented with $20 \mathrm{U}$ RNasin (Promega), $50 \mu \mathrm{g} /$ $\mathrm{mL}$ actinomycin D (Sigma), $10 \mu \mathrm{Ci}$ of Uridine $5^{\prime}-\left[\alpha^{-32} \mathrm{P}\right]-$ triphosphate, triethylammonium salt $(3,000 \mathrm{Ci} / \mathrm{mmol}$, Amersham Biosciences), $0.5 \mathrm{mM}$ each of the remaining NTP and $10 \mu \mathrm{M}$ UTP. Serial dilutions of each compounds were prepared in $100 \%$ dimethyl sulfoxide (DMSO), and treated with final concentration of $5 \%$ DMSO. After the reaction mixtures were incubated for $2 \mathrm{~h}$ at $30^{\circ} \mathrm{C}$, they were stopped by adding proteinase $\mathrm{K}$. RNA products were extracted with Phenol/Chloroform, precipitated with ethanol, and analyzed by $8 \%$ polyacrylamide gel electrophoresis (PAGE) under denaturing condition with $8 \mathrm{M}$ urea.

For filter binding RdRp assays, $1 \mu \mathrm{g}$ of poly(rA), $2.5 \mu \mathrm{g}$ of oligo(U $)_{16}$ and $1 \mu \mathrm{Ci}$ of $\left[5,6-{ }^{3} \mathrm{H}\right] \mathrm{Uridine} 5$ '-triphosphate, ammonium salt (50 Ci/mmol, Amersham Biosciences) were used as described above in place of 3'-X RNA and Uridine $5^{\prime}-\left[\alpha-{ }^{32} \mathrm{P}\right]$ triphosphate. 5-fold serial dilutions of $10 \mathrm{mM}$ stock test compounds in DMSO were prepared with final concentrations ranging from 100 to $0.03 \mu \mathrm{M}$. After the reaction ends, the products were precipitated with $10 \%$ trichloroacetic acid (TCA) and applied to a UniFilter-96, GF/B (PerkinElmer) using Cell Harvester (Packard). The 
96-well filters were washed 5 times with $10 \%$ TCA and 5 times with $95 \%$ EtOH, dried, and counted using a Packard TopCount microplate reader.

The HTS RdRp scintillation proximity assay (SPA) was carried out in 96-well plates using $50 \mathrm{nM}$ enzyme, $1 \mu \mathrm{Ci}$ of $\left[5,6-{ }^{3} \mathrm{H}\right]$ Uridine 5'-triphosphate, $10 \mu \mathrm{M}$ UTP, $250 \mathrm{nM} 5$ 'biotinylated oligo(U) ${ }_{16} /$ poly(rA), $20 \mu \mathrm{M}$ of tested compounds in $\mathrm{RdRp}$ buffer. The $100 \mu \mathrm{L}$ reaction was terminated after $3 \mathrm{~h}$ at $30{ }^{\circ} \mathrm{C}$ upon addition of equal volume of Streptavidin SPA beads (Amersham Biosciences) in RdRp buffer containing $160 \mathrm{mM}$ EDTA. After incubation at room temperature for overnight, the plates were counted using a Packard TopCount microplate reader.

Intracellular HCV RNA Analysis. HCV subgenomic replicon clone pNK5.1 cells ${ }^{11,12}$ were plated at a density of 5 $\times 10^{4}$ cells per well in a 24 -well plates at $37^{\circ} \mathrm{C}$ and $5 \% \mathrm{CO}_{2}$ with Dulbecco's modified essential medium containing $10 \%$ fetal bovine serum and $1 \mathrm{mg} / \mathrm{mL}$ Geneticin. After allowing overnight for cell attachment, $2 \mu \mathrm{L}$ of compound dilution was added to the medium. Briefly, six 2.5-folds dilutions of $10 \mathrm{mM}$ stock test compounds in DMSO were prepared with final concentration ranging from 20 to $0.2 \mu \mathrm{M}$. Plates were incubated for $40 \mathrm{~h}$, until they reached $80 \%$ confluence. After removal of medium, $1 \mathrm{~mL}$ of TRI REAGENT (Molecular Research Center, Inc.) was added to each well and RNA was purified according to the manufacturer's recommendations. The RNA level of HCV RNA was determined by RNA dot blot. The RNA dot blot was hybridized with Deoxycytidine $5^{\prime}-\left[\alpha-{ }^{32} \mathrm{P}\right]$ triphosphate-labeled probes synthesized from NS5B dsDNA fragment (nucleotides 6201-7333) as template using random priming method. The blot was hybridized according to manufacturer's instructions (BIO-RAD) and

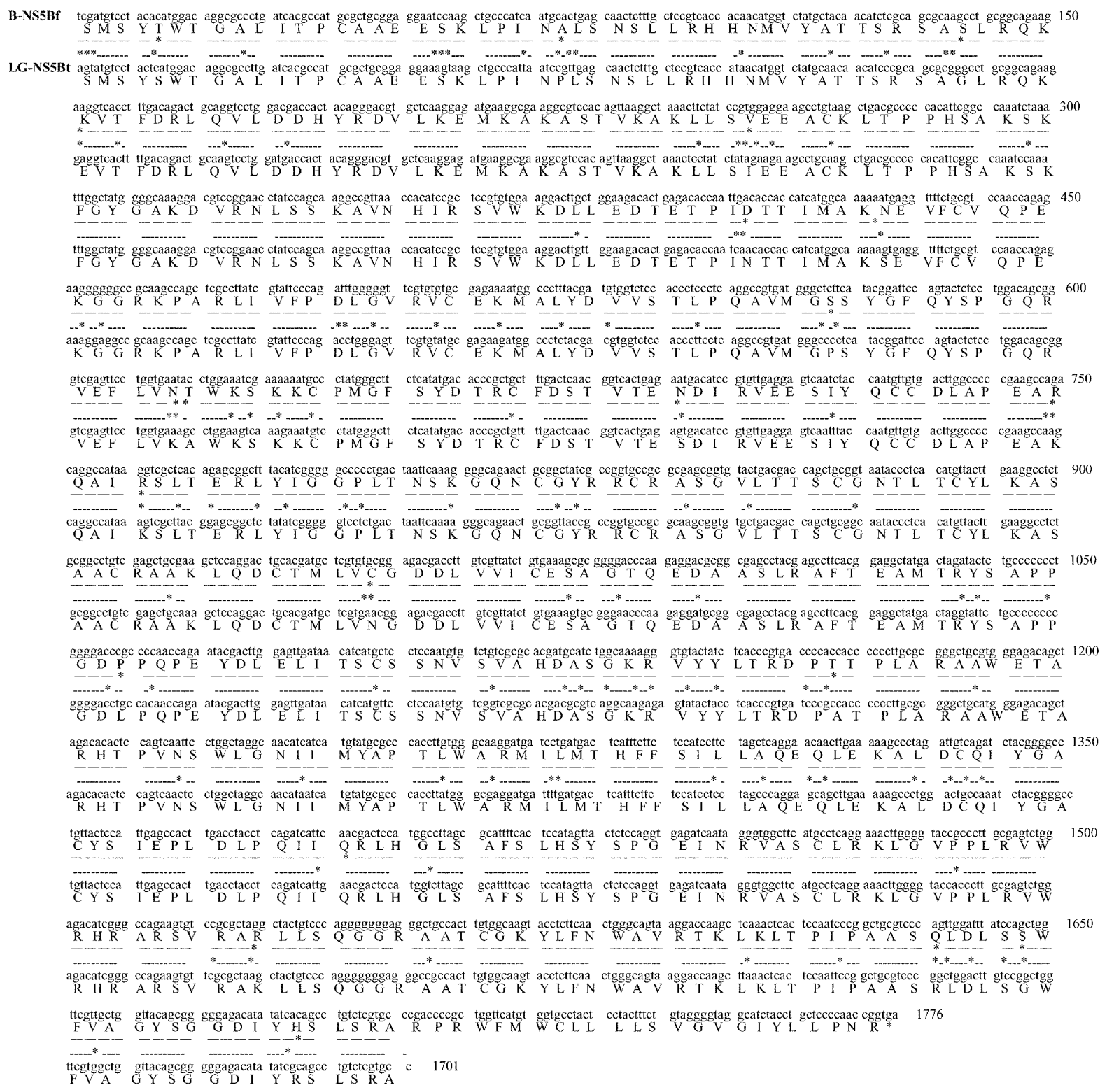

Figure 1. Nucleotide and deduced amino acid sequence of HCV NS5B region from a Korean patient. The compared nucleotide and deduced amino acid sequence homologies were $92.7 \%$ and $98.7 \%$ respectively with the reported genotype $1 \mathrm{~b}$ sequence. 
analyzed after an overnight exposure with a ChemiImager 4400 v5.5 program (Alpha Innotech Corporation).

Evaluation of Cellular Toxicity. HCV subgenomic replicon clone pNK5.1 cells were plated and treated with compounds as mentioned above, but excluding with final concentrations ranging from 100 to $1 \mu \mathrm{M}$. MTT $(0.5 \mathrm{mg} /$ $\mathrm{mL}$ ) was added to each well. After cells were then incubated for $4 \mathrm{~h}$ at $37{ }^{\circ} \mathrm{C}$, media were removed. $100 \%$ DMSO was added to each well to solubilize the MTT formazan crystals, and the plates were incubated with gently rocking. Absorbance at $450 \mathrm{~nm}$ was measured with a microplate reader .

Kinetic Measurements and Competition Assay with UTP. NS5B assays for mechanistic studies were performed similar to the filter binding RdRp assay described above, with the following modifications. Briefly, $5 \mu \mathrm{L}$ of $5 \times$ concentrated inhibitor solutions or DMSO control was added followed by $10 \mu \mathrm{L}$ of $10 \times$ RdRp buffer $(200 \mathrm{mM}$ Tris, $\mathrm{pH} 7.5,10 \mathrm{mM} \mathrm{MgCl}_{2}, 1.5 \mathrm{mM} \mathrm{MnCl}_{2}, 250 \mathrm{mM} \mathrm{KCl}$, $0.25 \%$ Tween $20,10 \%$ glycerol, $10 \mathrm{mM}$ DTT), poly(rA)/ oligo(U) $)_{16}$ ( primer-template), $10 \mu \mathrm{L}$ of UTP dilutions (top concentration containing $30 \mu \mathrm{M}$ UTP, $1 \mu \mathrm{Ci}$ of [5,6$\left.{ }^{3} \mathrm{H}\right]$ Uridine 5 '-triphosphate), and started with $10 \mu \mathrm{L}$ of enzyme mix (560 nM NS5B in reaction buffer) in $100 \mu \mathrm{L}$ total volume.

\section{Results and Discussion}

HCV NS5B genome of a Korean isolate was cloned from cDNA of a single chronic active hepatitis $\mathrm{C}$ patient. The nucleotide sequence and deduced amino acid sequence were compared with the reported $1 \mathrm{~b}$ genotype (Fig. 1). The percentage identity of the nucleotide and deduced amino acid sequence was $92.7 \%$ and $98.7 \%$, respectively, compared with the reported genotype $1 \mathrm{~b}$ sequence. ${ }^{12-14}$ Since NS5B is considered to have a key function in RNA replication, it is perhaps not surprising that the NS5B protein is highly conserved among the reported $1 \mathrm{~b}$ isolates.

The NS5B genome of the Korean $\mathrm{HCV}$ isolate was amplified with polymerase chain reaction methods. HCV cDNA was prepared from a single patient serum. The PCR product was digested with $\mathrm{NheI}$ and $\mathrm{XhoI}$ at sites engineered in the primers, and directionally cloned into pET-21b (Novagen) to produce a recombinant protein with a Cterminal 24 amino acid deletion.

E. coli BL21(DE3) containing the pET21b-NS5Bt plasmid produced a protein of approximately $65 \mathrm{kDa}$ under appropriate conditions (Fig. 2). As the expressed protein at $37^{\circ} \mathrm{C}$ with IPTG induction was found in insoluble fractions, we have made efforts to reduce the inclusion body formation. Many culture conditions including reduced concentration of IPTG, longer expression period, lowered expression temperature of to $15^{\circ} \mathrm{C}$ and increased aeration of the cultures were applied to produce more soluble NS5B proteins in E. coli culture. When cultures were reached to an OD 600 of $0.6-0.8$ at $37{ }^{\circ} \mathrm{C}$, IPTG was added to a final concentration of 0.5 $\mathrm{mM}$. Cultures were continued at $15^{\circ} \mathrm{C}$. Expression of the 65

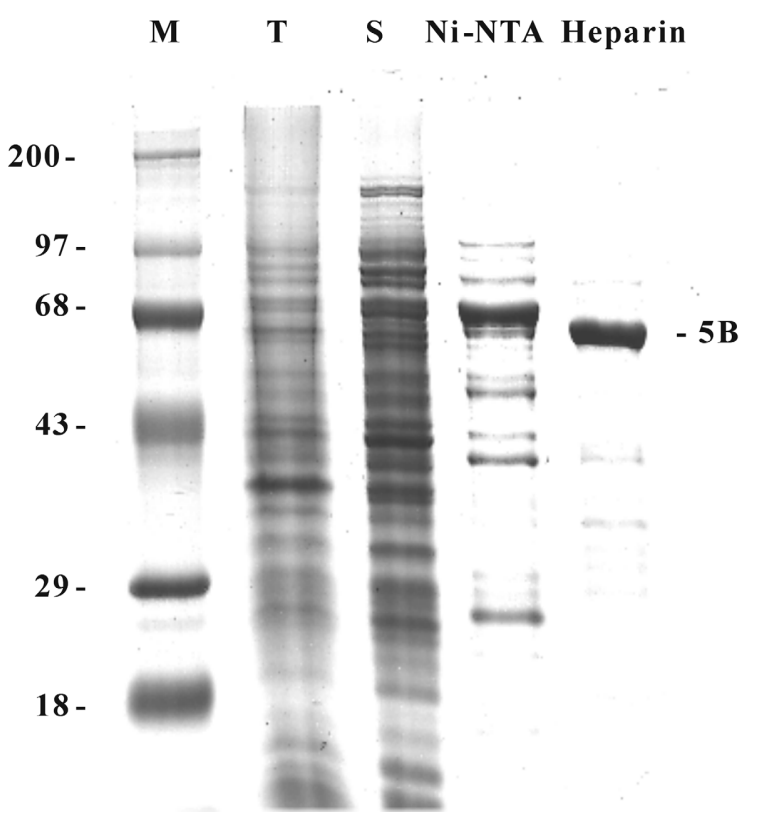

Figure 2. Expression and Purification of HCV NS5B in E. coli cells containing pET21b-NS5Bt. M, molecular size markers; T, total cell lysate; S, soluble fraction; Ni-NTA, pools from Ni-NTA chromatography; Heparin, pools from Heparin column chromatography.

$\mathrm{kDa}$ protein reached a maximum $15 \mathrm{~h}$ after the addition of IPTG (Fig. 2). Cell pellets were harvested and sonicated on ice. The cleared lysate obtained by centrifugation was applied to Ni-NTA resin and heparin resin consecutively. The purified NS5B protein could be used for the RdRp assay without further purification (Fig. 2). In case highly purified enzyme is needed, ion exchange column chromatography and desalting process were applied as described in Materials and Methods.

The ability of the purified NS5B enzyme to catalyze a RdRp reaction was determined with a polymerase assay by using several inhibitors and a 404 base RNA template (3'-X RNA), representing the 3'-end of the positive HCV RNA strand. Briefly, the purified protein was incubated with 3'-X RNA in a total volume of $40 \mu \mathrm{L}$ of RdRp buffer, $10 \mu \mathrm{Ci}$ of Uridine $5^{\prime}-\left[\alpha_{-}^{32} \mathrm{P}\right]$ triphosphate, $0.5 \mathrm{mM}$ each of the remaining NTP and $10 \mu \mathrm{M}$ UTP. Serial dilutions of each inhibitor were prepared in $100 \%$ DMSO, and treated with a final concentration of 5\% DMSO. After incubation for $2 \mathrm{~h}$ at $30{ }^{\circ} \mathrm{C}$, the reaction mixtures were analyzed by $8 \%$ PAGE under denaturing condition with $8 \mathrm{M}$ urea. Pyrophosphate, the pyrophosphate analogs (phosphonoacetic acid and phosphonoformic acid) and inhibitors of several DNAdependent DNA polymerases (GDP, dGTP and ddCTP) had no significant effects in concentrations up to $100 \mu \mathrm{M}$ (Fig. 3A). A moderate inhibition of RdRp activity was obtained with cerulenin, a specific inhibitor of fatty acylation and sterol biosynthesis. It was shown that cerulenin blocks poliovirus replication in infected cells. ${ }^{16}$ Also inhibitors of several DNA-dependent RNA polymerases such as mycophenolic acid and gliotoxin show a weak inhibition at high concentrations (Fig. 3B). However, ddUTP as a general 
(A) ddCTP (UM)

$\begin{array}{llllll}0 & 0.1 & 1 & 10 & 100 & 3^{\prime} X\end{array}$
(B) Gliotoxin (UM)

$00.111010025050010003^{\prime} X$
(C) ddUTP (UM)

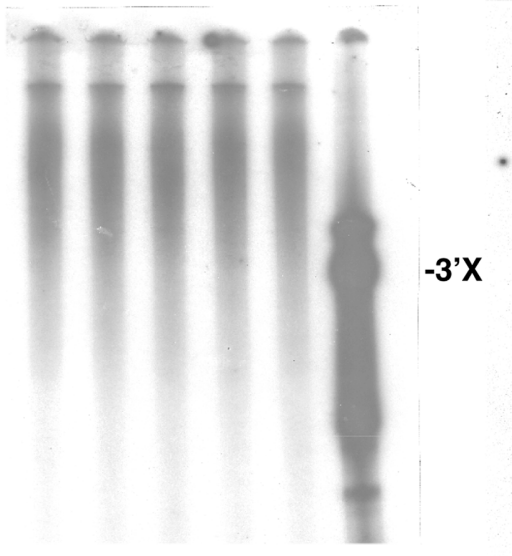

R E E $\begin{array}{llllllll} & 0 & 0.1 & 1 & 10 & 100 & 250 & 3\end{array}$
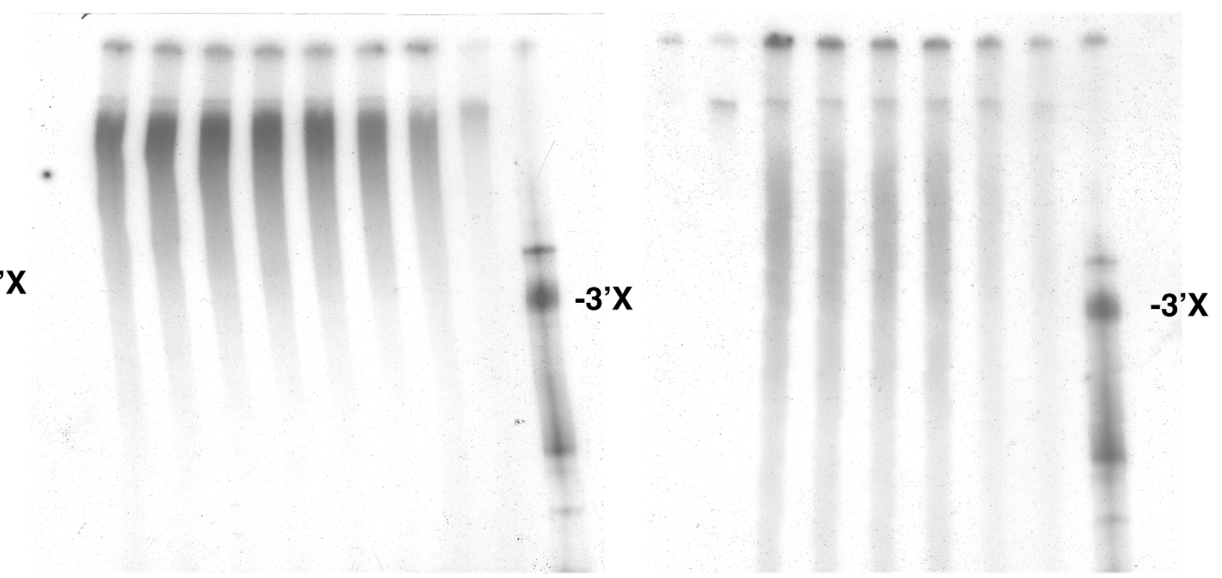

Figure 3. Effects of substrate analogs and inhibitors on RdRp activity. (A) Gel-based RdRp assays were performed as described in Materials and methods in the presence of $0.1 \mu \mathrm{M}, 1.0 \mu \mathrm{M}, 10 \mu \mathrm{M}$, or $100 \mu \mathrm{M}$ ddCTP. (B) Gel-based RdRp assays were performed in the presence of $0.1,1.0,10,100,250,500$, or $1000 \mu \mathrm{M}$ gliotoxin. (C) Gel-based RdRp assays were performed in the presence of $0.1,1.0,10,100$, or 250 $\mu \mathrm{M}$ ddUTP.

inhibitor of RNA polymerase, shows much stronger inhibition at $100 \mu \mathrm{M}$ (Fig. 3C), suggesting that the purified enzyme behaviors like RdRp.

In summary, the properties described here for NS5B of $\mathrm{HCV}$ are very similar to those reported for several picornaviral polymerases, ${ }^{17-19}$ and they suggest that the NS5B enzymes are closely related in function and possibly in structure to the picornaviral polymerases.

Since NS5B is the key player in RNA replication, the RdRp assay might be used as a starting point for the development of an antiviral therapy. Therefore, we measured inhibitory effects with a $50 \%$ inhibitory concentration $\left(\mathrm{IC}_{50}\right)$ of two known inhibitors (Fig. 4). Inhibitors, named Merck I and II, have the reported IC $_{50}$ values of $0.7 \mu \mathrm{M}$ and $0.056 \mu \mathrm{M}$, respectively. ${ }^{20}$ Our measurements with the purified NS5B protein show an excellent dose-dependency on the compounds. $\mathrm{IC}_{50}$ values were determined from doseresponse curves (Fig. 4) using 6 concentrations for each compound. Curves were fitted to data points using nonlinear regression analysis and $\mathrm{IC}_{50}$ values were interpolated from the resulting curves using Microsoft Excel software. We

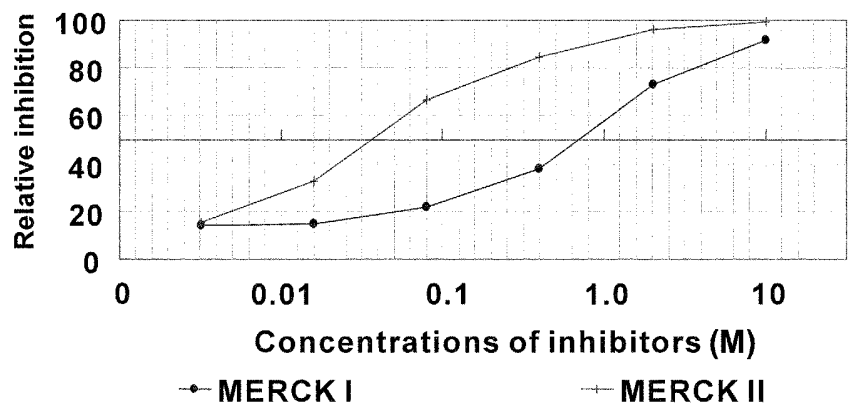

Figure 4. Inhibition of the RdRp activity by the reported specific RdRp inhibitors. The reactions were performed in the presence of increasing concentrations of inhibitors. found that the measured $\mathrm{IC}_{50}$ values were very similar to the reported values (Table 1 ).

Recently, a three-dimensional structure of the HCV polymerase was solved in complex with $\mathrm{RNA}^{21}$ as well as in a complex with nucleoside triphosphates. ${ }^{22}$ Three distinct nucleotide-binding sites were observed in the catalytic center of HCV RdRp whose geometry was remarkably similar to that observed in the initiation complex of the RNA phage $\Phi 6 \mathrm{RdRp}^{23}$ An unexpected result of this study was the observation of a GTP-binding site on the enzyme surface at the interface between the finger and thumb domains, $30 \AA$ away from the polymerase catalytic center. ${ }^{22}$ This previously unidentified

GTP pocket was proposed to be a potential allosteric regulatory site that could modulate alternative interactions between the two domains during the conformational change of the enzyme that is required for efficient initiation. The presence of a unique nucleotide-binding site away from the

Table 1. IC $\mathrm{I}_{50}$ measurements of Merck compound I and II, and their chemical structures

\begin{tabular}{ccc}
\hline & MERCK I & MERCK II \\
\hline $\begin{array}{c}\text { Filter binding method } \\
\left(\mathrm{IC}_{50}\right)\end{array}$ & $0.28 \mu \mathrm{M}$ & $0.07 \mu \mathrm{M}$ \\
\hline $\begin{array}{c}\text { Altamura } \text { et al., } 1999 \\
\left(\mathrm{IC}_{50}\right)\end{array}$ & $0.7 \mu \mathrm{M}$ & $0.056 \mu \mathrm{M}$ \\
MERCK I
\end{tabular}




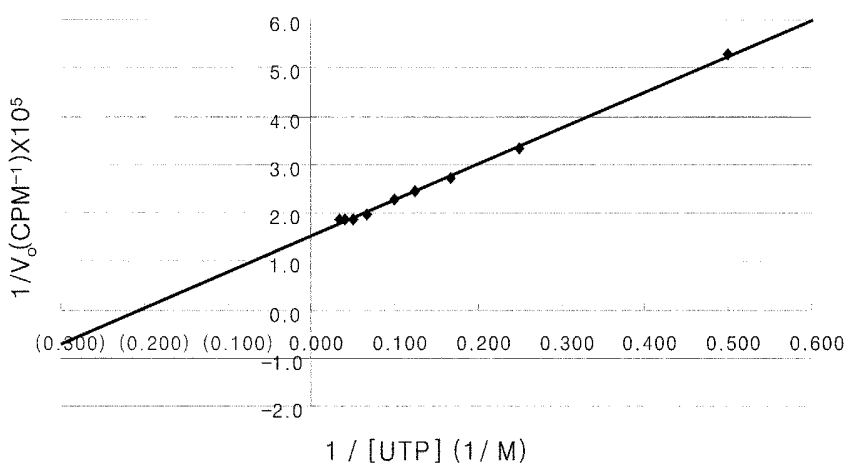

Figure 5. Measurements of $K m$ value varying UTP concentrations on RdRp activity. RdRp assays were performed as described in Materials and Methods using the homopolymeric template, poly(rA)/oligo $\mathrm{U}_{16}$ and the following concentrations of the limiting nucleotide UTP: $30 \mu \mathrm{M}, 25 \mu \mathrm{M}, 20 \mu \mathrm{M}, 15 \mu \mathrm{M}, 10 \mu \mathrm{M}, 8 \mu \mathrm{M}, 6$ $\mu \mathrm{M}, 4 \mu \mathrm{M}, 2 \mu \mathrm{M}, 1 \mu \mathrm{M}, 0.5 \mu \mathrm{M}, 0.25 \mu \mathrm{M}$, and $0.1 \mu \mathrm{M}$. Data are represented as double-reciprocal plots (1/V vs $1 /[\mathrm{S}])$.

enzyme catalytic center could potentially provide an attractive target for allosteric inhibitors of the $\mathrm{HCV}$ polymerase reaction. Therefore, we established high-throughput screening assays using a SPA bead system with our own RdRp activity conditions. High-throughput screening of the LGLS proprietary compound archive identified a novel rhodanine NS5B inhibitor whose chemical structure is shown in Figure 6. Compound LB80524 demonstrated inhibition of NS5B polymerization activity with a calculated $\mathrm{IC}_{50}$ value of 5.0 iM. Subsequent kinetic experiments demonstrated that the $K m$ for UTP was $4.9 \mu \mathrm{M}$ (Fig. 5). Furthermore, mechanistic enzymology studies with compound LB80524 suggest that this inhibitor exhibits a kinetic behavior consistent with a reversible, noncompetitive mechanism of inhibition with respect to UTP. A noncompetitive inhibition of UTP incorporation by the compound LB80524 was displayed as a Lineweaver-Burk plot (Fig. 7). To determine the inhibitory mode of LB80524 in RNA synthesis catalyzed by NS5B, reactions were run in which the concentrations of UTP and LB80524 were varied, respectively. Double-reciprocal plots of the data as shown in Figure 7 indicated noncompetitive inhibition of activity by LB80524 with varying concentrations of UTP. However, the rhodanine compound was able to inhibit the HCV replication only weakly in $\mathrm{HCV}$ replicon cells $\left(\mathrm{EC}_{50}=40 \mu \mathrm{M}\right)$. The implication associated with activity in the replicon cells is that the inhibitor was not able to access the perinuclear membrane easily, the site of viral

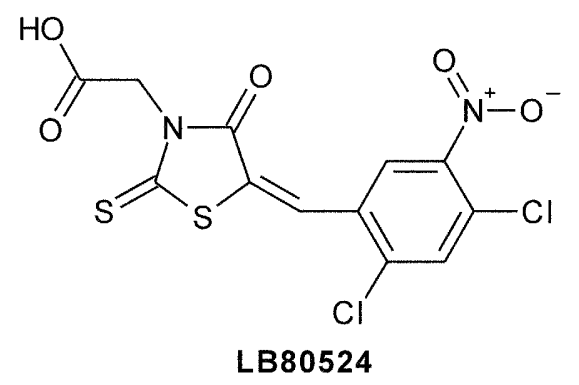

Figure 6. Chemical Structure of LB80524.

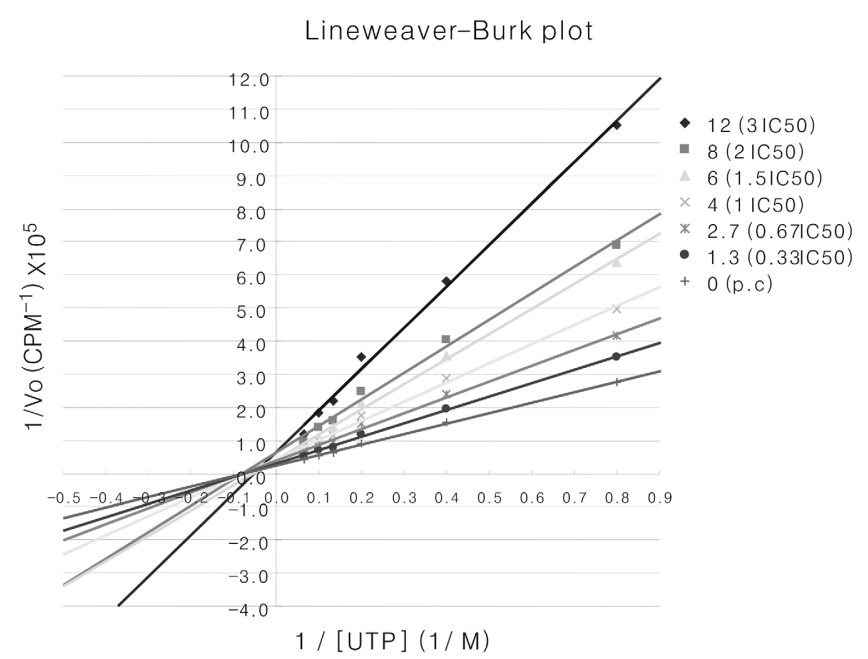

Figure 7. Mode of inhibition by LB80524 of NS5B-catalyzed RNA-dependent RNA polymerization. Oligo(U) 16 -primed homopolymeric poly(rA) RdRp reaction included the substrate UTP from $30 \mu \mathrm{M}$ to $0.1 \mu \mathrm{M}$, and also $0 \mu \mathrm{M}, 1.3 \mu \mathrm{M}, 2.7 \mu \mathrm{M}, 4 \mu \mathrm{M}, 6$ $\mu \mathrm{M}$, or $8 \mu \mathrm{M}$ LB80524. Data were fit to a noncompetitive mechanism.

\section{RNA synthesis.}

In conclusion we isolated a HCV NS5B genome (genotype $1 b$ ) from a Korean hepatitis $C$ patient, cloned it, and expressed it in E. coli. With the highly purified NS5B protein, we established in vitro systems for RdRp activity to identify potential polymerase inhibitors. We found a potent inhibitor against HCV RdRp by utilizing the established in vitro systems, and characterized the mode of inhibition by investigating kinetic studies. This assay is a highly reproducible, non-labor intensive, and cost effective assay. In addition this assay is easily adaptable to automation in a high-throughput format.

Acknowledgement. We thank Dr. J. R. Choi and Dr. J.-T. Hwang for providing compounds, Dr. H. S. Yoon for HTS assay, and Mr. T. G. Kim for the replicon assay.

\section{References}

1. Ali, S.; Tardif, K. D.; Siddiqui, A. J. Virol. 2003, 76, 12001.

2. Behrens, S.-E.; Tomei, L.; De Francesco, R. EMBO J. 1996, 15, 12.

3. Rice, C. M. Fields Virology; Fields, B. N.; Knipe, D. M.; Howley, P. M., Eds.; Raven Press: New York, N.Y., 1996; p 931.

4. Seeff, L. B. Am. J. Med. 1999, 107, 10S.

5. World Health Organization. Wkly. Epidemiol. Rec. 1996, 71, 346.

6. Davis, G. L.; Esteban-Mur, R.; Rustgi, V.; Hoefs, J.; Gordon, S. C.; Trepo, C.; Shiffman, M. L.; Zeuzem, S.; Craxi, A.; Ling, M. H.; Albrecht, J. N. Engl. J. Med. 1998, 339, 1493.

7. Fried, M. W.; Shiffman, M.; Reddy, K. R.; Smith, C.; Marinos, G.; Goncales, F. L. J.; Haussinger, D.; Diago, M.; Carosi, G.; Dhumeaux, D.; Craxi, A.; Lin, A.; Hoffman, J.; Yu, J. N. Engl. J. Med. 2002, 347, 975 .

8. Choo, Q. L.; Kuo, G.; Weiner, A. J.; Overby, L. R.; Bradley, D. W.; Houghton, M. Science 1989, 244, 359.

9. Lohmann, V.; Körner, F.; Herian, U.; Bartenschlager, R. J. Virol. 1997, 71, 8416.

10. Sambrook, L.; Fritsch, E. F.; Maniatis, T. Molecular Cloning: a 
Laboratory Manual, 2nd ed.; Cold Spring Harbor Laboratory: Cold Spring Harbor , N.Y. 1989.

11. Krieger, N.; Lohmann, V.; Bartenschlager, R. Journal of Virology 2001, 75, 4614.

12. Lohmann, V.; Korner, F.; Koch, J.; Herian, U.; Theilmann, L.; Bartenschlager, R. Science 1999, 285, 110.

13. Hotta, H.; Handajani, R.; Lusida, M. I.; Soemarto, W.; Doi, H.; Miyajima, H.; Homma, M. J. Clin. Microbiol. 1994, 32, 3049.

14. Stuyver, L.; van Arnhem, W.; Wyseur, A.; Hernandez, F.; Delaporte, E.; Maertens, G. Proc. Natl. Acad. Sci. U. S. A. 1994, $91,10134$.

15. Bartenschlager, R. Intervirology 1997, 40, 378.

16. Guinea, R.; Carrasco, L. EMBO J. 1990, 9, 2011.
17. Morrow, C. D.; Lubinski, J.; Hocko, J.; Gibbons, G. F.; Dasgupta, A. J. Virol. 1985, 53, 266.

18. Neufeld, K. L.; Richards, O. C.; Ehrenfeld, E. J. Biol. Chem. 1991, 266, 24212.

19. Sankar, S.; Porter, A. G. J. Biol. Chem. 1992, 267, 10168.

20. Altamura, S.; Tomei, L.; Koch, U.; Neuner, P.; Summa, V. World Patent No. WO 00/06529, 1999.

21. O'Farrell, D.; Trowbridge, R.; Rowlands, D.; Jager, J. J. Mol. Biol. 2003, 326, 1025.

22. Bressanelli, S.; Tomei, L.; Rey, F. A.; De Francesco, R. J. Virol. 2002, 76, 3482.

23. Butcher, S. J.; Grimes, J. M.; Makeyev, E. V.; Bamford, D. H.; Stuart, D. I. Nature 2001, 410, 235. 